\title{
If Crisis or War Comes: A Study of Risk Communication of Eight European Union Member States
}

\author{
Evangelia Petridou (D), Erna Danielsson (D), Anna \\ Olofsson (D), Minna Lundgren ${ }^{(1)}$, and Christine Große
}

\author{
Risk and Crisis Research Center, Mid Sweden University, Östersund, Sweden
}

\begin{abstract}
How do European Union (EU) member states communicate risks to their citizens? In this study, we define risk communication as the information provided by different levels of government to citizens regarding possible future crises to which the general public might be subjected. We seek to answer the following questions: Are there any patterns in the risk communication strategies among EU member states in terms of the sender of information, the message conveyed, the method used, and the intended audience? Finally, to what extent is the state involved in ensuring the safety of its citizens? To tackle these questions, we examine the risk communication strategy of eight countries: Sweden, Finland, Germany, England, France, Estonia, Greece, and Cyprus. Our data consist of governmental web sites, publications, campaigns, and other modes of communication, such as videos posted on YouTube, with questions centering on institutional actors, methods of delivery, content, and effectiveness. We find that the institutional architecture of risk communication aligns with the broad administrative system of each member state. Countries tend to focus on risks that are specific to their context, with Sweden and, to a lesser extent, Germany having a special focus on consequences and providing guidelines to the public on how to survive for a certain period of time in the absence of the state. Especially in Sweden, though the state is a salient actor in risk communication through the dissemination of information at the agency level, the state retreats while urging the resilient citizen to take control of his or her own crisis management.
\end{abstract}

KEYWORDS: Risk communication; comparative studies; European politics; resilience; public policy

In May 2018, the Swedish Civil Contingencies Agency (MSB) sent a pamphlet to all 4.7 million Swedish households containing information on how to deal with the consequences of contemporary emergencies, titled If Crisis or War Comes. This brochure was an updated version of a series of information sheets from World War II and the Cold War

CONTACT Evangelia Petridou, PhD•E-mail: evangelia.petridou@miun.se•Risk and Crisis Research Center, Mid Sweden University, Kunskapens Väg 1, 831 25, Östersund, Sweden 
era (Dwyer, 2018) and began with a message stating that even though Sweden was safer than many other countries, it faced threats that might jeopardize its security and independence (Myndigheten för samhällsskydd och beredskap, 2018).

Recent events with national repercussions for Sweden include the looming Russian geopolitical threat, the terrorist attack in central Stockholm in April 2017, the forest fires in Västmanland of 2014 (see Öhman, Giritli Nygren, \& Olofsson, 2016), and the extensive forest fires in summer 2018. The cultural imagination of realized disasters and many other chimerical ones influences the response to current challenges. The "emergency imaginary" dictates the perception of disasters among professionals (Gregersen \& Winkel Holm, n.d.), and in turn, this perception determines what risks professionals communicate to the public and how they do so. More specifically, Calhoun (2008) theorized that framing events as emergencies shapes the way in which we understand aberrant (perhaps) events, such as inter alia crises, disasters, and international conflicts, and delineates the range of acceptable actions. The emergency imaginary is a way of conceptualizing problematic events, foregrounding their "unpredictability, abnormality, and brevity" while concomitantly pointing to their attendant corollary: intervention (Calhoun, 2008, p. 375). Calhoun treated the issue of international emergencies and humanitarian intervention, but theoretically, we can scale down and consider problematic events at the micro level and what intervention at the individual level might look like.

Calhoun (2008) also noted that attention must be paid to the ways risks and threats are conceptualized so that we may understand "the social organization of fear" (p. 381), on one hand, and, on the other, how the sense of vulnerability is distributed. This is not a new concept in risk communication research, and in this study, we consider risk communication specifically at the preparedness phase, which

is designed to understand and address the public's awareness and knowledge gaps related to risk events, to elicit desired preparedness behaviors through identifying and utilizing effective communication channels, to ensure adequate understanding, and to educate about what actions to take when messages are issued. (Sheppard, Janoske, \& Liu, 2012, p. 11; see also Leiss, 1996; Lofstedt, 2010) 
The empirical impetus for this research was the striking catholic and centralized nature of the aforementioned communique issued by the Swedish state. Our study aims at filling the apparent lacuna of crosscountry European comparisons when it comes to risk communication at the preparedness phase (see, however, Infanti et al., 2013; Lofstedt, 2010; Tourenq, Boustras, \& Gutteling, 2017 for a set of guidelines). From a theoretical perspective, we seek to uncover the architecture (actors, institutions, and the degree of their involvement, message, method, and audience) as part of the risk communication process. In other words, our research question is as follows: How is this imaginary of emergencies in Europe reflected in the content of risk communication messages issued by governmental organizations?

To answer this question, we conducted a comparative study of eight European Union (EU) member states with the objective to map the institutional risk communication structure, the messages that these actors send, how these messages are conveyed, and to whom.

\section{Literature Review}

Risk communication as a research area is broad and diversified, including areas such as risk perception, risk and emotions, social construction of risk, media communication, framing, social movements, public engagement, and, not least, crisis communication (Cho, Reimer, \& McComas, 2006; Ulmer, Sellnow, \& Seeger, 2011). Therefore, whenever we study "risk communication," we need to define our object of inquiry and thus delimit our investigation. In this article, we investigated national and subnational risk communication and more specifically the way different European countries have designed their risk communication architecture regarding possible future crises where the receiver is the public at large.

Empirically and theoretically focused research has targeted the receivers' information seeking (Alaszewski, 2005), perception of risk communication tools and messages (Slovic, 1999), trust in communicators (Renn \& Levine, 1991), vulnerabilities (Fothergill, Maestas, \& Darlington, 1999), and sociocultural contexts (Wardman, 2014). Although such research has produced insight and guidelines regarding these different core aspects of risk communication, relatively few studies 
have focused on public policy, particularly in a comparative perspective. Two exceptions are the Organisation for Economic Co-operation and Development (OECD) report Trends in Risk Communication Policies and Practices from 2016, which reviewed the risk communication systems of 19 countries, and the 2017 study authored by Tourenq, Boustras, and Gutteling that compared the policy design of Cyprus, France, and the Netherlands (see also Infanti et al.s 2013 literature review on effective risk communication in Europe). Reflecting the risk communication literature, the OECD (2016) defined six criteria for effective risk communication:

- Consistency across different risk communication tools.

- Two-way communication and interactive approaches.

- Accuracy and trust. Best available knowledge should be used in a transparent way.

- Accessibility of information for citizens, NGOs (non-governmental organizations) and private organizations to seek and use.

- Information adapted to the audience's cognitive capacities, their exposure or vulnerability.

- Cross-sectoral and trans-boundary, reflecting the cross-border, multiple dimensions and possible cascading effects of threats and hazards. (p. 30)

The report illustrates how risk communication systems may be understood and evaluated based on these criteria and the state of the art (e.g., Hampel, 2006; Leiss, 1996; Renn \& Levine, 1991; Ulmer et al., 2011). See Table 1.

The conclusions of the report partly indicate that national risk communication needs to be more inclusive and interactive and to focus more on prevention, that is, provide more information about what people can do to mitigate their exposure to risk. Tourenq, Boustras, and Gutteling (2017) argued similarly in a comparative study of Cyprus, France, and the Netherlands. They evaluated available information on the countries' websites based on the assumption that two-way communication enhances individual preparedness and resilience. They found that both France and the Netherlands had interactive communication and that 
TABLE 1 Core Elements of a National Risk Communication System

\begin{tabular}{ll}
\hline \multicolumn{1}{c}{ Element } & \multicolumn{1}{c}{ Description } \\
\hline Governance & $\begin{array}{l}\text { Who is in charge of risk communication, and what is the } \\
\text { institutional structure of risk communication governance? }\end{array}$ \\
$\begin{array}{l}\text { Considering all hazards and } \\
\text { forward thinking }\end{array}$ & $\begin{array}{l}\text { How comprehensive and forward oriented are national risk } \\
\text { communication practices? }\end{array}$ \\
$\begin{array}{l}\text { Purpose of communication } \\
\text { and activation of target }\end{array}$ & $\begin{array}{l}\text { What is the purpose of countries' risk communication, } \\
\text { and how is the target audience involved to effectively } \\
\text { communicate risk? }\end{array}$ \\
$\begin{array}{l}\text { Focus on prevention } \\
\text { Happing into innovation }\end{array}$ & $\begin{array}{l}\text { What is the role of innovative technologies in countries' } \\
\text { practices? }\end{array}$ \\
risk communication practices?
\end{tabular}

Note. Based on OECD (2016).

the Netherlands particularly focused on the individual citizen's ability not only to manage but also to prepare for crises. The risk communication of Cyprus, conversely, was exclusively one way, providing expert information for the purpose of "educating people" (Tourenq et al., 2017, p. 547). Arguably, there exist two different assumptions on which risk communication architecture is based: the "educate the public" approach, where citizens are seen as passive and unknowledgeable, and the "resilient citizen" approach, where citizens are not only active and knowledgeable but also seeking responsibility for themselves and the community (see Aradau, 2014).

This leads us to the orientation of this article, which is a critical perspective of risk and risk communication as constituent components of the imaginary of emergencies (Boisseau, Feltey, Flynn, Gelfand, \& Triece, 2008; Calhoun, 2008). Risk and its communication create a demand for changes to society and to individuals: Risk may be viewed as a concept intent on exercising power (Wilkinson, 2009). The notion of risk can thus serve as a control technique expressing the interaction 
of power relationships (Hannah-Moffat \& O’Malley, 2007). This opens up for questions of how notions of risk come to "delimit what it is possible to think and say at a particular time, what purpose does this serve, and to whose benefit?" (Wardman, 2008, p. 1633), or as Calhoun (2008, p. 381) put it, how the conceptualization of risk impacts on the social organization of fear. In some cases, inequalities are (re)produced by modes of governance, including the use of "risk" as a regulatory regime that is shaped by power imbalances (Giritli Nygren, Öhman, \& Olofsson, 2017; Montelius \& Giritli Nygren, 2014). Risk communication often aims at supporting vulnerable populations, but by making the power dimension of risk communication and its intersection with other lines of power visible, we allow for an analysis of risk communication practices that does not hide the reproduction of existing norms and social inequality.

For this reason, we pay special attention to the issue of representativeness. The audience of risk communication consists of diverse publics, necessitating a certain tailoring of the message to establish trust and collaboration (Janoske, Liu, \& Sheppard, 2012). Janoske et al. reported on children, the elderly and disabled, and racial and ethnic minorities. We considered risk communication aimed at transient populations as well as people living in rural areas in our study in an effort to broaden the diversity of publics under consideration.

In summary, there is a paucity of cross-country comparative research examining such issues as risk communication policies, institutional actors, the intended recipient and message content, and even fewer with a critical component. The extant international comparisons, though they provide an important starting point for thinking about risk communication in comparative terms, do not go far enough in addressing the imaginary of emergencies in Europe and nuances among countries under investigation. For example, Tourenq et al. (2017) mentioned factors such as "history, people, management, and lack of funds" (pp. 546-547) but do not go any further. This article adds to the limited knowledge of risk communication at the national and subnational levels (Infanti et al., 2013) but also expands the analysis with a systematic comparison among EU countries. Such comparison has a number of practical implications. Different countries often face not only similar 
risks but also risks that stretch over national boundaries. The insight into how countries perceive and communicate risk and prepare for crises has the potential to facilitate coordination in the face of an extraordinary event. A recent example of a European civil protection mobilization took place in summer 2018 when the coordinated effort of eight countries assisted Sweden in battling destructive forest fires (European Commission, 2018).

\section{Research Design, Method, and Data}

This is a qualitative systematic comparison aiming at capturing as much variation as possible among EU member states. To fulfill the objective of maximum variation in the cases selected, the logic of comparison is a variation of the "most different systems" logic, which is a logic of systematic cross-country comparison first articulated by Przeworski and Teune (1970; see also Collier, 1993; Meckstroth, 1975). Rather than uncovering causal relationships, the eight-country comparison contrasted contexts to establish a framework for understanding how risk communication processes play out in different ways in each context. This interpretive dimension in social sciences is accommodated within small $\mathrm{N}$ comparative studies as elaborated in Skocpol and Somers (1980). The authors posited that asking the same or similar analytical questions in contrasting contexts may highlight divergences, making them more transparent-though this is not a causal analysis producing sweeping theory.

To that end, the selection of cases covered the entire geographic gamut of the EU 28. Geography is relevant because it partly (though not exclusively) determines what kind of events might be conceived as threats by each country. Additionally, geography functions as a kind of proxy for the historical contingences idiosyncratic to each country. Traditionally, Greece and Cyprus belong to the European South; France and Germany are in Western Europe (though Germany is sometimes classified as Central) and Sweden and Finland belong to Northern Europe, while Estonia is part of Eastern Europe. The British Isles here are considered a part of Western Europe, ${ }^{1}$ though elsewhere they may be classified as a region of their own (Libraries of the University of Minnesota, 2012). 
TABLE 2 Thematic Guide for Data Analysis

\begin{tabular}{ll}
\hline \multicolumn{1}{c}{ Category } & \multicolumn{1}{c}{ Constituent questions } \\
\hline Institutional actors & What institutional actors are involved in the risk \\
communication process? & Are there any nongovernmental organizations involved, \\
and if so, how? & How is the message communicated to the public? \\
Is the communication in any language other than the \\
official language for each country investigated? If that is the \\
case, is the message the same? \\
Are there any provisions to spread the message to \\
subgroups of the population, such as (a) people with \\
disabilities, (b) nonnative speakers (tourists or immigrants), \\
(c) people in elderly care, (d) the homeless. \\
What kinds of media (videos, pictures, text) are used to \\
convey the message? \\
What kinds of risks and potential crises do the countries \\
under comparison take up? \\
Are there any campaigns (with or without a timeline) \\
geared toward raising public awareness when it comes to \\
crisis preparedness? If so, what do these campaigns look \\
like? \\
Have there been any evaluations assessing the effectiveness \\
of the risk communication tools?
\end{tabular}

Additionally, the countries under examination covered the entire typology range of public administration systems in Europe (Kuhlmann \& Wollmann, 2014). This is relevant because risk communication is part of the public administration arrangements of each case in terms of institutions involved, message conveyed, and so on. France and Greece belong to the Continental European Napoleonic model, characterized by a strong centralized government and a powerful centralized bureaucracy, which means that the subnational and local levels are considered to be subordinate. In contrast, in the Continental European Federal model (Germany), the central bureaucracy is weaker, and the subnational, decentralized institutions have more power. In the Scandinavian model (Sweden, Finland), the administrative structure is also highly 
decentralized, while the most salient feature of the Anglo-Saxon model (England and, to a certain extent, Cyprus) is new public management decentralized managerial practices (Kuhlmann \& Wollmann, 2014). In Estonia, we capture the postcommunist environment with the attendant interventionist state.

Our investigation was conducted on publicly available text and images (still and video) comprising risk communication material at the preparedness phase. Data included information about risks, warnings, self-protection guidelines, and other publications geared toward various publics on outlets (official websites, YouTube channels, and Facebook groups) authored and curated by public entities of, or related to, civil protection or civil defense. We, the authors, have native or near-native linguistic competence as well as country-specific knowledge of the countries we compared. This eliminated any linguistic or cultural misunderstandings and allowed for a nuanced analysis of texts and images. We asked the same questions of the data, thematically arranged and summarized in Table 2. We used these questions to address the core elements of a national risk communication system (see Table 1) and, in turn, unpack the imaginary of emergencies.

\section{Results}

In this section, we present the results of the data analysis based on the thematic guide presented in Table 2 . The purpose of the analysis is to understand how the imaginary of emergencies (Calhoun, 2008) is reflected in the risk communication practices of the eight selected countries by fleshing out any convergent as well as divergent points among them, structured after the items in Table 1.

\section{Governance Arrangements: Who Is in Charge of Risk Communication?}

The degree of the centralization of responsibility for risk communication varies among the countries under comparison, generally along the lines of their administrative system. The institutional risk communication architecture in the Scandinavian countries follows the corporatist model with civil society and the local level being important actors and 
builds on collaboration among agencies and municipalities as well as the involvement of private and volunteer sectors. The Swedish Civil Contingencies Agency (MSB), placed under the Ministry of Justice, and the Finnish department for Rescue Services have strategic, coordinating, and supportive responsibilities. More specifically, the Swedish MSB provides information to the public mainly through two websites (http:// www.dinsakerket.se/ and http://www.krisinformation.se/), though the websites of county administrative boards and municipalities also convey information to the public. The Finnish Rescue Services are responsible for preventing accidents, providing emergency services, and protecting the population in exceptional circumstances at the regional level and are also responsible for civil defense (Finnish Ministry of the Interior, 2018).

Conversely, France and Greece, in Western and Southern Europe, respectively, follow the continental Napoleonic model, and unsurprisingly, the national government is in charge of what is communicated and how. In France, the General Secretariat for Defense and National Security (SGDSN) in the Ministry of the Interior coordinates the national plans that serve as decision support tools at the national level. The secretariat supports the prime minister and the president in their role as crisis managers and is also responsible for civil defense (Gouvernement Français, 2018a). Similarly, in Greece, civil protection issues are handled by the General Secretariat for Civil Protection established in 1995 and tasked with coordinating risk communication to citizens both in general terms and during exceptional circumstances (Republic of Greece, 2002).

The Estonian Rescue Board, the third largest public service institution in Estonia, is the main actor in risk communication (Päästeamet, 2017), whereas in England, the substance and method of delivery of risk communication are the responsibility of Local Resilience Forums. These are not legal entities but "collaborative mechanisms" that "have a collective responsibility to plan, prepare and communicate in a multiagency environment" (Cabinet Office, 2013, p. 3). Most of these follow police force boundaries (Garton Grimwood, 2017). The organization with leading responsibilities in emergency management is the Civil Contingencies Secretariat in the Cabinet Office, established in 2001 (Cabinet Office, 2013). 
In Germany, the institution responsible for informing the public of risks and potential crises is the German Federal Office of Civil Protection and Disaster Assistance (Bundesamt für Bevölkerungsschutz und Katastrophenhilfe; BBK) under the German Interior Ministry (BMI), which is the highest federal authority. The main purpose of the $\mathrm{BBK}$ is to prepare the public for times of crisis; coordinate all the bodies involved before, during, and after a crisis; and provide the physical and psychological support necessary for citizens' well-being (Bundesamt für Bevölkerungsschutz und Katastrophenhilfe [BBK], 2018a, 2018b). Municipalities are active in civil defense (Zivilschutz- und Katastrophenhilfegesetz, 1997/2009, para. 5/1), and they use information available on the BBK website. Additionally, a host of voluntary organizations is actively involved in communicating information to the public.

This is not the case in Cyprus, where for one to be a volunteer, one must be a citizen of the Republic of Cyprus and register by submitting an online form. Strategic policy decisions are made by the General Civil Defense Administration, while there are also five district administrations (Cyprus Ministry of the Interior, 2018a). The Civil Defense Force has the added responsibility to protect citizens in periods of hostilities (Cyprus Ministry of the Interior, 2018b).

\section{Which Hazards Are Communicated, and to What Extent Is the Focus on Prevention?}

Greece, Estonia, Cyprus, and France focus on various known risks and hazards-such as earthquakes; inclement weather; landslides; and chemical, biological, radiological, and nuclear (CBRN) threats-with a focus on those threats specific to each country. For example, Greece places a particular emphasis on forest fires, which occur annually and to a certain extent are due to either human error or arson, but there is no mention of the threat of terrorist attack or hostilities. The current geopolitical alignment of Greece and its self-reference as an interstice between East and West may exclude the imaginary of a space for terrorist attacks of the kind similar to those elsewhere in Europe. However, emphasis is put on home fires as, due to the economic crisis, people have started using braziers and burning various materials in their 
fireplaces. There is a marked focus on prevention of these well-defined risks (General Secretariat for Civil Protection, 2018).

In Estonia in 2016, a spatial analysis of home fires showed a correlation with socioeconomic factors. In Tallinn, for example, home fires occur more often in residential buildings from the Soviet era, where inhabitants in general are older, have lower income, and live alone and where Estonian is not their first language. In a departure from the other countries under comparison in this study, the Estonian Rescue Board conducts home visits during which they advise residents on how to make their home safer. In 2016, the board carried out more than 17,000 home consultations, covering $2.7 \%$ of Estonian households. It also organizes safety awareness days and regular school visits (Päästeamet, 2017).

France covers a broader array of risks with a number of sectoral plans (national and territorial), each corresponding to a previously identified risk or threat. A set of complementary plans, Plan Vigipirate (the Pirate Family), specifically addresses the capacity of the state and relevant stakeholders to deal with terrorist attacks (Gouvernement Français, 2018b). At the national website, there is a specific section on risk prevention (Gourvernment Français, 2018c). Under the slogan "Better prepared, better informed, you will be able to act in case of problems and help your loved ones in the face of an emergency," video tutorials address a number of risks. The Ministry of Interior Affairs's website contains a section about personal security ("Ma sécurité") where citizens can learn how to avoid accidents inside and outside the home with a special section for the elderly (French Ministry of the Interior, 2018).

The Civil Defense Force in Cyprus takes up the same risks as Greece with additional information on what to do in the event of hostile ac-

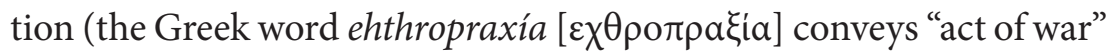
rather than "terrorist attack"), including the case of a bombing campaign by another nation and fires caused by such action. The message is unequivocal: "Self-protection is basically the responsibility of all of us. Take the necessary measures in good time" (Civil Defense Force, 2002, n.p.).

While this quote stems from the threat of invasion in Cyprus, the Greater Manchester Local Resilience Forum has a similar message on 
its website: "Whilst we can't prevent emergencies happening, we can plan ahead to minimise the impact" (Greater Manchester Prepared, 2018 , n.p.), admitting that the state is unable to keep the citizenry safe through prevention measures and that safety is the responsibility of the individual. In addition to England, risk communication strategies in Sweden and Germany are characterized by an all-hazards approach that focuses on consequences and the open admission that risks cannot be prevented.

Both Sweden and Germany have incorporated preparedness campaigns in their risk communication strategies, in which the public is urged to have a store of supplies at hand to survive a certain period of time during which a complete disruption of societal functions is imagined, including loss of electricity, water, means of transportation, and any other amenity that one takes for granted in an advanced Western democracy. The German BKK's website recommends storing enough food and water to survive for at least 2 weeks in the worst-case scenario (BBK, 2017, p.10), though conflicting guidelines from the Ministry of the Interior advising 5 days' worth of water supplies and 10 days' worth of food created confusion among the citizens (Bundesministerium des Innern, für Bau und Heimat, 2016).

In Sweden, to raise public awareness, MSB ran a weeklong campaign on May 8, 2017, titled "Upside Down" (Upp och Ner). This was the second such MSB-led campaign, and its target group was women between 45 and 64 years of age. The campaign centered on disruption in electricity supply and focused on the necessities each household ought to have to be able to function during a days-long blackout. This campaign essentially reinforced the earlier message communicated on the websites of Swedish municipalities and county administrative boards: "this is what you need to have at home during a crisis" (detta behöver du ha hemma vid en kris).

In Finland, a very different 72-hour campaign mainly consisted of meetings between nongovernmental organization (NGO) representatives and the public. The campaign was partly carried out online, but the main focus was on face-to-face workshops. Apart from the official 72-hour website (http://www.72tuntia.fi/), which is available in Finnish, Swedish, and English, several organizations, for example, Suomen 
Pelastusalan Keskusjärjestö (the Finnish National Rescue Association; SPEK), also distributed printed information about the 72-hour campaign. Notably, SPEK, which is a national consultancy and service organization for fire and rescue services responsible for training NGO workers, has used MSB YouTube videos in their training material in the Swedish speaking areas of Finland. Whereas the 72-hour campaign is mainly geared toward the urban population, SPEK also maintains a project called "Our Safe Village" that is geared toward small-town preparedness for everyday disruptions and accidents (Suomen Pelastusalan Keskusjärjestö, 2018).

\section{Tap Into Innovation: The Use of Technology in Risk Communication}

With the exception of Cyprus, all countries use YouTube to post TV spots and educational films. They also use Facebook and Twitter as information dissemination tools. Sweden, England, France, and Germany have launched smartphone applications varying in scope and interactivity. For example, the French government describes the aims of the app (called SAIP) as follows: "It is part of an approach to develop a culture of vigilance and security of our citizens, initiated with the awareness campaign 'React in case of terrorist attack' which gives practical instructions based on: 'escape, hide, alert'"(Gouvernement Français, 2018d, n.p.).

Conversely, the German app NINA aims at informing the public about current weather situations; national, regional, and local threats; and, in particular, large-scale emergencies (Großschadenslagen). The dissemination of local-specific information is limited due to the service availability (BBK, 2018c).

\section{Know Your Impact}

It is unclear whether the countries under comparison know the impact of their risk communication strategies. Though the institutional actors involved have the mandate to evaluate (e.g., Republic of Greece, 2002), no evaluations of risk communication strategies are available on governmental websites. Estonia, however, is an exception to this: The Estonian Rescue Board seeks public feedback to measure satisfaction 
and trust in the board's operations. Feedback was gathered after rescue events, home consultations, training sessions, safety days, and construction site inspections (Päästeamet, 2017).

\section{Communicate-to Whom?}

Most countries convey some information in English, though the English version lacks in depth and detail. The "easy language" versions of the Swedish and German websites are also limited. Where the automated translation function of Google is used, the results can range from confusing to amusing. At the two sides of the continuum are Greece, with information in six professionally translated languages, and Cyprus and England, with information only in Greek and English, respectively.

The image of society that comes across by the risk communication content and techniques is fairly traditional in terms of family structures, households, and people. For example, images of people with obvious disabilities are few and far between.

Generally speaking, spatial images are generic, though the environment is implicitly urban. This is deduced not by what is said but rather by what is left unsaid. For example, there is no information specific to the countryside. Exceptions to these are the "Safe Village" campaign in Finland and the information from the English Local Resilience Forums, because the latter are very localized and the information fits the local context.

\section{Communicate-for What Purpose, and What Is the Role of the Recipient?}

All eight EU countries, to various degrees, advise the public on how to prepare, act, and protect themselves and others during events ranging from inclement weather to acts of war by providing specific information on these risks. We did not find any instances of explicitly interactive communication. Even in countries in which there exist smartphone apps, the information seems to be flowing one way. Having said this, the content of information seems to activate the recipients: They are urged to have a family contingency plan, to actively protect their homes from fires, and to be vigilant and inform if they see suspicious objects left unattended in public spaces. 
As mentioned elsewhere in this article, Sweden and, to a certain extent, Germany have incorporated a specific kind of campaign in their risk communication strategies, a campaign focused on consequences rather than risks that urges the public to have supplies to last them for some time in case of complete societal breakdown due to a mostly unspecified-and largely irrelevant to the substance of the communication-risk. Sweden alone is sending this information in print form to all the households in the country.

This focus on the consequences of an unspecified catastrophic event has had the unforeseen effect of commodifying risk in Sweden. The emphasis on materiality has created a marketplace for the products that the state recommends be in every household storage space, such as canned water.

We argue that this is a case of the citizen being nudged into a perceived resilient state by the admission of the public sector that it will be unavailable at the onset of an unspecified extreme event. Additionally, this is a rather static idea of resilience, as the focus is on the materiality of preparedness rather than social relations and making sure that one's neighbor is safe as well. This discourse echoes the U.S. Federal Emergency Management Agency (FEMA), which shifts the responsibility of emergency management from the federal to the state, local, community, and individual levels (Federal Emergency Management Agency, 2018).

\section{Conclusions and Suggestions for Further Research}

The eight countries under comparison cover the gamut of geographies and administrative systems. Moreover, two pairs of countries-Greece and Cyprus and, to a certain extent, Finland and Sweden-share a common language and the culture and heritage that are embedded in language. One would expect similarities in the way the imaginary of emergencies is reflected in the risk communication policies of Greece and Cyprus, both part of the European South but with different administrative systems, but that is not the case. Finland runs a campaign with the same title as Sweden's, shares the same message, and uses material from MSB in their information tool kit in the Swedish-speaking parts of the country. However, the focus is on training volunteer personnel 
and not blanket information dissemination to the public. There are also two countries that share a (post)colonial relationship - the United Kingdom and Cyprus. While the United Kingdom and Cyprus share the same administrative system to some extent, a vestige from an earlier colonial relationship, Cyprus is alone in the degree of militarization of civil defense, and the United Kingdom is the foremost country arranging its risk communication structure under the term resilience. The factor overriding a common heritage (with Greece) or a common administrative system (with the United Kingdom) is previous experience with an extraordinary event, and Cyprus has had a very recent experience of military action.

The pattern of institutional structures that organizes risk communication in all the countries under investigation aligns with their administrative systems. The institution that deals with risk communication is a variation of a civil protection entity normally under the ministry of the interior, though in the United Kingdom, the central institution is in the Cabinet Office. Incidentally, this is the equivalent of the Swedish Prime Minister's Office, where the Secretariat for Crisis Management was placed when it was first created in Sweden in 2007 (Petridou \& Sparf, 2017). Sweden and the United Kingdom use the term civil contingencies, whereas Finland, Cyprus, and Estonia use the term civil defense. The remaining countries use civil protection. There is a marked military component in the Cypriot structure, but perhaps this is unsurprising given that its capital is the only remaining divided capital in the world. There are military echoes in Finland and Estonia as well, which is again perhaps unsurprising given their historical contingencies and recent geopolitical events.

The pattern of central control with decentralized input holds more or less in all countries, including the federal Germany. The U.K. system is very different, however, where the central level has only strategic functions and all the risk communication competencies have been devolved to the regional level in what are called Local Resilience Forums. This makes for a lack of uniformity in information that is communicated to the public, as each resilience forum is region specific. At the same time, the public receives information relevant to them and not a generic version of risk communication. In the other countries under comparison, 
information is reproduced at the subnational level from the national website, which can make for a "one-size-fits-all" information packet missing local nuances, such as center-periphery issues. In France, there is a marked fragmentation of information disseminated to the public with several ministries being involved in the process. Notably, this fragmentation is at the national level, as the responsibility for risk communication rests with the national government. Conversely, in Greece, for example, the Civil Contingencies Secretariat informs citizens of risks, including risks that are corollaries of adverse weather, whereas in France, the Ministry of Ecological and Solidarity Transition informs on these risks.

Volunteer organizations are present in all the countries in question, though not to the same degree. This ranges from a controlled registration system in Cyprus to very active involvement in Finland to a separate volunteer organization coordination entity in the United Kingdom. Other than Germany and Finland, in which volunteer organizations provide risk communication, in most of the countries in question, the communication is handled by government at various levels. For example, in Germany, crisis management rests heavily on the engagement of volunteers in local organizations such as fire brigades and rescue services. These local organizations communicate information about risks related to their area of responsibility (e.g., fire) and how to become a member and participate in crisis management.

Websites are the foremost vehicle for communicating information to the public, though in Sweden, France, England, and Germany (notably, in the more economically developed Northern and Western Europe), the national government also employs apps as early warning systems. The authorities also use social media to disseminate information: Facebook, Twitter, and YouTube, though the extent varies among the countries under comparison. In Estonia, the public sector conducts home visits to disseminate self-protection guidelines, a possible vestige of an era of an omnipresent state. The range of state involvement in the amount and scope of information communicated is quite broad, ranging from the aforementioned home visits to rather sparse information from the Civil Defense Force in Cyprus, where the only videos found on YouTube were recordings of military parades. 
Notably, the strategic risk communication policy gaze of the United Kingdom and Sweden seems to be fixed westward toward the United States in terms of devolution and a responsibilitization of the individual, respectively. Especially in Sweden, though the state is a salient actor in risk communication through the dissemination of information at the agency level, the state retreats while nudging at the resilient citizen, urging him or her to take control of his or her own crisis management.

Finally, the comparison revealed that though there are similarities in the way the imaginary of emergencies (Calhoun, 2008) is reflected in risk communication policies in EU countries, there are also major differences. With the exception of governance arrangements, which follow each country's administrative system, we did not find stable patterns connecting political administrative systems and geography to the risk communication policy of all the countries under consideration. The study, however, allowed us to tease out and showcase factors of risk communication policy by comparing and contrasting across eight European contexts.

Having said this, we argue that more knowledge is needed regarding the effects of campaigns and risk communication activities directed toward the various publics, both in terms of these publics' understanding, knowledge, and preparedness and in terms of possible differences between their diverse resources to respond. Furthermore, there is a need for better understanding of the motives behind the various approaches that different countries apply. Our European comparison shed some light on the national-level processes, but more cross-country comparisons within Europe and beyond are needed to position our results in a global context. In addition to breadth, we also advocate depth. There is a need for comparative field research and interviews with the institutional actors and publics involved in the communication process to understand the construction of the imaginary of emergencies in different national contexts. Finally, it would be beneficial for researchers and policy makers alike to understand the diffusion of risk communication policies and the national environments that ideationally influence the policy process. 


\section{Acknowledgement}

This study was financed by a grant from the Swedish Civil Contingencies Agency (MSB), contract date October 2, 2017. We would like to thank the anonymous reviewers and our colleagues at the Risk and Crisis Research Center at Mid Sweden University who provided valuable feedback on earlier versions of this article.

Evangelia Petridou, $\mathrm{PhD}$, is assistant professor of public administration at Mid Sweden University and the Risk and Crisis Research Center (RCR) in Sweden. She is a public policy and public administration scholar. Evie's recent work has appeared in the Policy Studies Journal (2014), Policy Studies (2018), and Policy and Society (with Jörgen Sparf, 2017), and she was co-editor of Entrepreneurship in the Polis: Understanding Political Entrepreneurship (2015).

Erna Danielsson, $\mathrm{PhD}$, is associate professor of sociology at Mid Sweden University and director of the Risk and Crisis Research Center (RCR). Erna has extensive experience as project manager within the area of cross-sectoral collaboration during crises. Recently, she has been especially interested in volunteers in disaster. She is on the board of the Research Council at the Swedish Civil Contingency Agency (MSB) and of the Research Council of Norway, Fire Security Program. She is actively engaged in questions on research ethics.

Anna Olofsson, $\mathrm{PhD}$, is professor of sociology, dean of the Faculty of Human Sciences at Mid Sweden University, and former director of the Risk and Crisis Research Centre (RCR). Her research focuses on risk and its role on the individual and in society. She is particularly interested in the stratification of society in terms of gender, ethnicity, sexuality, and class and its consequences for the management of risks and understandings of risk and risk communication. She has coedited one book in Swedish and one book in English, and she has contributed to six international edited volumes. She lectures on courses in risk communication, risk perceptions, and risk theory and supervises and examines at all levels. 
Minna Lundgren, $\mathrm{PhD}$, sociology, is assistant professor and is pursuing a postdoctoral research project on risk communication in heterogeneous environments.

Christine Große is a PhD student at Mid Sweden University in the Department of Information Systems and Technology. She examines implications for critical infrastructure and protection that are associated with systemic effects in complex planning environments. She is involved in a project concerning Swedish emergency planning. She holds a Phil Licentiate in Systems Science, a MSc in information security, and a BSc in business informatics.

\section{ORCID}

Evangelia Petridou (1) https://orcid.org/oooo-0oo1-7316-4899

Erna Danielsson (1) https://orcid.org/oooo-0002-6899-4035

Anna Olofsson (D) https://orcid.org/0000-0001-5000-311X

Minna Lundgren (10 https://orcid.org/oooo-0002-7512-9066

Christine Große (1) https://orcid.org/oooo-0003-4869-5094

\section{Note}

1. For practical reasons, and due to the devolved nature of the United Kingdom, we focused on English Local Resilience forums and did not look at any data in Scotland, Wales, or Northern Ireland. Additionally, all the material for Cyprus refers to actors and processes in the Republic of Cyprus. No information was collected regarding practices in the so-called Turkish Republic of Northern Cyprus, an entity recognized solely by Turkey. 


\section{References}

Alaszewski, A. (2005). Risk communication: Identifying the importance of social context. Health, Risk, and Society, 7, 101-105. https://doi.org/10.1080 $/ 13698570500148905$

Aradau, C. (2014). The promise of security: Resilience, surprise and epistemic politics. Resilience: International Policies, Practices, and Discourses, 2, 73-87. https://doi.org/10.1080/21693293.2014.914765

Boisseau, T. J., Feltey, K., Flynn, K., Gelfand, L., \& Triece, M. (2008). New Orleans: A special issue on the gender politics of place and displacement. NWSA Journal, 2o, vii-xvii. Retrieved from http://www.jstor.org /stable/40071292

Bundesamt für Bevölkerungsschutz und Katastrophenhilfe. (2017). Disasters alarm: Guide for emergency preparedness and correct action in emergency situations (4th ed.). Bonn, Germany: Author.

Bundesamt für Bevölkerungsschutz und Katastrophenhilfe. (2018a). Homepage. Retrieved from https://www.bbk.bund.de/EN/Home/home_node .html

Bundesamt für Bevölkerungsschutz und Katastrophenhilfe. (2018b). Federal office. Retrieved from https://www.bbk.bund.de/EN/FederalOffice/fed eraloffice_node.html

Bundesamt für Bevölkerungsschutz und Katastrophenhilfe. (2018c). Warnapp NINA. Retrieved from https://www.bbk.bund.de/DE/NINA/Warn -App_NINA_node.html

Bundesministerium des Innern, für Bau und Heimat. (2016). Konzeption zivile Verteidigung [Conception of civil defense]. Retrieved from https://www .bmi.bund.de/SharedDocs/Downloads/DE/Broschueren/2016/konzeption -zivile-verteidigung.pdf

Cabinet Office. (2013). The role of local resilience forums. Retrieved from https://www.gov.uk/government/publications/the-role-of-local-resilience -forums-a-reference-document

Calhoun, C. (2008). A world of emergencies: Fear, intervention, and the limits of cosmopolitan order. Canadian Review of Sociology/Revue canadienne de sociologie, 41, 373-395. https://doi.org/10.1111/j.1755-618X.2004.tboo783.x

Cho, H., Reimer, T., \& McComas, K. A. (Eds.). (2015). The SAGE handbook of risk communication. New York, NY: Sage. https://doi.org/10.4135/978148 3387918 
Collier, D. (1993). The comparative method. In A. W. Finifter (Ed.), Political science: The state of the discipline II. Washington, DC: American Political Science Association.

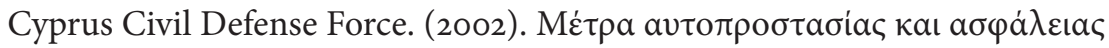

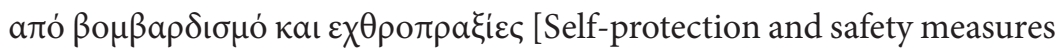
from bombing and acts of war]. Retrieved from http://www.moi.gov.cy

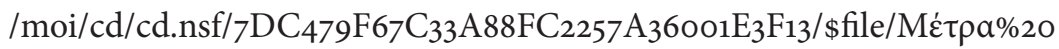

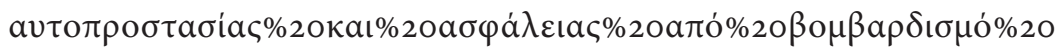
$\kappa \propto\llcorner \% 20 \varepsilon \chi \theta \rho о \pi \rho а \xi i \varepsilon \varsigma . p d f$

Cyprus Ministry of the Interior. (2018a). Civil Defense Force. Retrieved from http://www.moi.gov.cy/moi/cd/cd.nsf/index_gr/index_gr

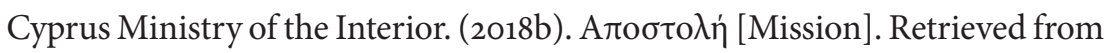
http://www.moi.gov.cy/moi/cd/cd.nsf/pageo3_gr/pageo3_gr

Dwyer, C. (2018, January 22). Unsettled by Russia, Sweden revives pamphlets on what do "if war comes." National Public Radio. Retrieved from https:// www.npr.org/sections/thetwo-way/2018/01/22/578893302/unsettled-by -russia-sweden-revives-pamphlets-on-what-to-do-if-war-comes

European Commission. (2018). Skogsbränder: EU koordinerar största insatsen någonsin $i$ Sverige [Forest fires: The EU is coordinating the largest operation ever in Sweden]. Retrieved from https://ec.europa.eu/sweden/news /skogsbränder-eu-koordinerar-största-insatsen-någonsin-i-sverige_sv Federal Emergency Management Agency. (2018). 2018-2022 strategic plan. Retrieved from https://www.fema.gov/media-library-data/1521736077767 -89fcoafeacb7a93bd7b6a1o91aaeba2b/strat_plan.pdf

Fothergill, A., Maestas, E. G., \& Darlington, J. D. (1999). Race, ethnicity and disasters in the United States: A review of the literature. Disaster, 23, 156-173. https://doi.org/10.1111/1467-7717.00111

Garton Grimwood, G. (2017). Dealing with civil contingencies: Emergency planning in the UK (Report No. 08016). London, England: House of Commons Library.

General Secretariat for Civil Protection. (2018). Self-protection guidelines. Retrieved from http://civilprotection.gr/el/disasters

Giritli Nygren, K., Öhman, A., \& Olofsson, A. (2017). Doing and undoing of risk. The mutual constitution of risk and heteronormativity in contemporary society. Journal of Risk Research, 20, 418-432. https://doi.org/10.1080 /13669877.2015.1088056

Gouvernement Français. (2018a). Protection of major risks. Retrieved from 
http://www.gouvernement.fr/risques/le-processus-de-gestion-de-crise Gouvernement Français. (2018b). Risks. Retrieved from http://www.gouver nement.fr/risques

Gouvernement Français. (2018c). The Vigipirate plan. Retrieved from http:// www.gouvernement.fr/vigipirate

Gouvernement Français. (2018d). L’application mobile SAIP: Système d'alerte et d'information des populations [The mobile phone application SAIP: A public alert system]. Retrieved from http://www.gouvernement.fr/appli -alerte-saip

Greater Manchester Prepared. (2018). Preparing yourself for an emergency. Retrieved from http://www.gmemergencyplanning.org.uk/info/20/preparing _yourself_for_an_emergency

Gregersen, N. H., \& Winkel Holm, I. (n.d.). Changing disasters: Imaginations. Retrieved from http://changingdisasters.ku.dk/about/imaginations/

Hampel, J. (2006). Different concepts of risk-A challenge for risk communication. International Journal of Medical Microbiology, 296, 5-10. https:// doi.org/10.1016/j.ijmm.2005.12.002

Hannah-Moffat, K., \& O’Malley, P. (Eds.). (2007). Gendered risks. London, England: Routledge. https://doi.org/10.4324/9780203940556

Infanti, J., Sixsmith, J., Barry, M. M., Núñez-Córdoba, J., OroviogicoecheaOrtega, C., \& Guillén-Grima, F. (2013). A literature review on effective risk communication for the prevention and control of communicable diseases in Europe. Stockholm, Sweden: ECDC. https://doi.org/10.1080/10810730.2 013.840701

Janoske, M., Liu, B., \& Sheppard, B. (2012). Understanding risk communication best practices: A guide for emergency managers and communicators. Retrieved from https://www.start.umd.edu/sites/default/files/files/publica tions/UnderstandingRiskCommunicationBestPractices.pdf

Kuhlmann, S., \& Wollmann, H. (2014). Introduction to comparative public administration. Cheltenham, England: Edward Elgar.

Leiss, W. (1996). Three phases in the evolution of risk communication practice. Annals of the American Academy of Political and Social Science, 545, 85-94. https://doi.org/10.1177/2Fooo2716296545001009

Libraries of the University of Minnesota. (2012). World regional geography: People, places, and globalization. Retrieved from http://open.lib.umn.edu /worldgeography/front-matter/publisher-information/ 
Lofstedt, R. E. (2010). Risk communication guidelines for Europe: A modest proposition. Journal of Risk Research, 13, 87-109. https://doi.org/10.1080 /13669870903126176

Meckstroth, T. W. (1975). "Most different systems" and "most similar systems": A study in the logic of comparative inquiry. Comparative Political Studies, 8, 132-157. https://doi.org/10.1177/2Foo1041407500800202

Finnish Ministry of the Interior. (2018). Civil defence protects the civilian population. Retrieved from http://intermin.fi/en/rescue-services/prepared ness/civil-defence

French Ministry of the Interior. (2018). Lancement de l'application mobile SAIP: Système d'alerte et d'information des populations [Launch of the mobile phone application SAIP: A public alert system]. Retrieved from https:// www.interieur.gouv.fr/Archives/Archives-des-actualites/2016-Actualites /Lancement-de-l-application-mobile-SAIP

Montelius, E., \& Giritli Nygren, K. (2014). “Doing” risk, “doing” difference: Towards an understanding of the intersections of risk, morality and taste. Health, Risk, and Society, 16, 431-443. https://doi.org/10.1080/13698575.2 014.934207

Myndigheten för samhällsskydd och beredskap. (2018). Om krisen eller kriget kommer [If crisis or war comes] (Publication No. MSB1186). Karlstad, Sweden: Author.

Öhman, S., Giritli Nygren, K., \& Olofsson, A. (2016). The (un)intended consequences of crisis communication in news media: A critical analysis. Critical Discourse Studies, 13, 515-530. https://doi.org/10.1080/17405904.2016.1174138 Organisation for Economic Co-operation and Development. (2016). Trends in risk communication policies and practices: OECD reviews of risk management policies. Paris, France: OECD Publishing.

Päästeamet. (2017). Estonian rescue board yearbook, 2016. Retrieved from https://www.rescue.ee/dotAsset/5879c895-d6bo-41d6-9cee-e1a7odif561a .pdf

Petridou, E., \& Sparf, J. (2017). For safety's sake: The strategies of institutional entrepreneurs and bureaucratic reforms in Swedish crisis management, 2001-2009. Policy and Society, 36, 556-574. https://doi.org/10.1080/1449 4035.2017.1369677

Przeworski, A., \& Teune, H. (1970). The logic of comparative social inquiry. New York, NY: John Wiley. 
Renn, O., \& Levine, D. (1991). Credibility and trust in risk communication. In R. Kasperson \& P. Stallen (Eds.), Communicating risks to the public (pp. 75-218). Dordrecht, Netherlands: Kluwer. https://doi.org/10.1007/978-94 -009-1952-5_10

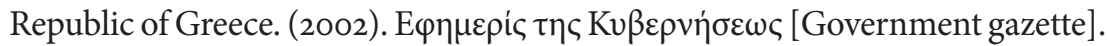
FEK 102, May 1.

Sheppard, B., Janoske, M., \& Liu, B. (2012). Understanding risk communication theory: A guide for emergency managers and communicators. College Park, MD: START. Retrieved from http://www.start.umd.edu/sites/default/files /files/publications/UnderstandingRiskCommunicationTheory.pdf

Skocpol, T., \& Somers, M. (1980). The uses of comparative history in macrosocial theory. Comparative Studies in Society and History, 22, 174-97. https:// doi.org/10.1017/So010417500009282

Slovic, P. (1999). Trust, emotion, sex, politics, and science: Surveying the riskassessment battlefield. Risk Analysis, 19, 689-701. https://doi.org/10.1111 /j.1539-6924.1999.tboo439.x

Suomen Pelastusalan Keskusjärjestö. (2018). Our safe village. Retrieved from http://www.kyläturvallisuus.fi/opas/Etusivu

Tourenq, S., Boustras, G., \& Gutteling, J. M. (2017). Risk communication policy design: Cyprus compared to France and the Netherlands. Journal of Risk Research, 20, 533-550. https://doi.org/10.1080/13669877.2015.1100656 Ulmer, R. R., Sellnow, T. L., \& Seeger, M. W. (2011). Effective crisis communication: Moving from crisis to opportunity (2nd ed.). Thousand Oaks, CA: Sage.

Wardman, J. K. (2008). The constitution of risk communication in advanced liberal societies. Risk Analysis, 28, 1619-1637. https://doi.org/10.1111/j.1539 $-6924.2008 .01108 . x$

Wardman, J. K. (2014). Sociocultural vectors of effective risk communication. Journal of Risk Research, 17, 1251-1257. https://doi.org/10.1080/13669877.2 014.942498

Wilkinson, I. (2009). Risk, vulnerability, and everyday life. London, England: Routledge. https://doi.org/10.4324/9780203030585

Zivilschutz- und Katastrophenhilfegesetz. (2009). Gesetz über den Zivilschutz und die Katastrophenhilfe des Bundes (Zivilschutz- und Katastrophenhilfegesetz): ZSKG. Bundesgesetzblatt, I2350. (Original work published 1997) 